Table 1. Estimated association between vitamin D levels and odds of organ-specific lupus disease activity, adjusting for age, race, sex, calendar year, prednisone use and plaquenil use

\begin{tabular}{|c|c|c|c|c|c|c|}
\hline \multirow[t]{2}{*}{ Vitamin D Level $(\mathrm{ng} / \mathrm{mL})$} & \multicolumn{2}{|c|}{$\begin{array}{c}\text { Immunologic Disease } \\
\text { Activity }\end{array}$} & \multicolumn{2}{|c|}{$\begin{array}{c}\text { Skin Disease } \\
\text { Activity }\end{array}$} & \multicolumn{2}{|c|}{$\begin{array}{c}\text { Renal Disease } \\
\text { Activity }\end{array}$} \\
\hline & OR $(95 \% \mathrm{Cl})$ & P-value & $\mathrm{OR}(95 \% \mathrm{Cl})$ & P-value & OR $(95 \% \mathrm{Cl})$ & P-value \\
\hline$<10(n=163)$ & $1.0(0.7,1.5)$ & 0.88 & $1.4(1.0,2.1)$ & 0.049 & $3.1(2.0,4.9)$ & $<0.0001$ \\
\hline 10 & $1.0(0.9,1.1)$ & 0.93 & $0.9(0.8,1.1)$ & 0.41 & $2.2(1.5,3.1)$ & $<0.0001$ \\
\hline 20 & $1.0(0.9,1.1)$ & 0.97 & $1.0(0.9,1.2)$ & 0.53 & $.2,2.0)$ & 0.0008 \\
\hline 59) & $1.0(0.9,1.1)$ & 0.78 & $1.1(1.0,1.2)$ & 0.13 & $1.2(0.9,1.5)$ & 0.23 \\
\hline $40-50(n=3578)$ & 1.0 (Ref Grp) & & 1.0 (Ref Grp) & & 1.0 (Ref Grp) & \\
\hline $50-60(n=2308)$ & $1.0(0.9,1.1)$ & 0.78 & $1.1(0.9,1.3)$ & 0.19 & $1.0(0.7,1.3)$ & 0.91 \\
\hline $60-70(n=929)$ & $1.0(0.9,1.2)$ & 0.98 & $1.0(0.8,1.3)$ & 0.74 & $0.8(0.5,1.3)$ & 0.33 \\
\hline $70-80(n=504)$ & $1.1(0.8,1.2)$ & 0.92 & $1.3(1.0,1.7)$ & 0.072 & $0.8(0.4,1.4)$ & 0.41 \\
\hline $80+(n=356)$ & $(1.1(0.9,1.4)$ & 0.42 & $1.4(1.0,1.9)$ & 0.072 & $0.6(0.3,1.6)$ & 0.32 \\
\hline
\end{tabular}

However, for skin activity, there was a significantly elevated risk among those in the very extreme levels of vitamin D. For Renal Disease Activity, there was a significantly higher rate of renal disease activity among those with low levels of vitamin D. In addition, there was a clear trend such that the higher the vitamin D, the lower the risk of renal disease activity.

We then conducted a "within person" analysis. In this analysis, each person serves as his own control, and the question is: "When a person has a vitamin $\mathrm{D}$ level lower than his/her average, are they more likely to have renal disease activity". Note, this analysis implicitly adjusts for race, sex, and all variables (measured and unmeasured) that are invariant within a person. The results are shown in Table 2.

Table 2. Within-person analysis of the relationship between vitamin D levels and renal activity adjusting for prednisone use, plaquenil use, and implicitly for all time-invariant characteristics

\begin{tabular}{lcc}
\hline Vitamin D Level & Odds Ratio & P-value \\
\hline $10 \mathrm{ng} / \mathrm{mL}$ or more lower than personal average & $1.5(1.3,1.8)$ & $<0.0001$ \\
Within $10 \mathrm{ng} / \mathrm{mL}$ of the personal average & $1.0($ Ref Grp) & \\
$10 \mathrm{ng} / \mathrm{mL}$ or more higher than personal average & $0.8(0.7,1.0)$ & 0.080
\end{tabular}

For Renal, it appears (based on the within-person analysis), that increasing vitamin $D$ results in a reduction in renal activity. Based on other analyses, it is clear this drop was mostly among those in the vitamin D deficiency range.

Conclusions: Low vitamin D is associated with cutaneous and renal SLE activity, but not with immunologic (low C3 or high anti-DNA) activity, in adjusted analyses. Disclosure of Interest: None declared

DOI: 10.1136/annrheumdis-2017-eular.4526

\section{AB0462 VITAMIN D SUPPLEMENTATION SIGNIFICANTLY REDUCES CHOLESTEROL IN SLE}

M. Petri ${ }^{1}$, L.S. Magder ${ }^{2} .{ }^{1}$ Johns Hopkins University School of Medicine; ${ }^{2}$ University of Maryland, Baltimore, United States

Background: The benefit of vitamin D on SLE global and renal activity have now been proven by both cohort studies and a clinical trial. The benefits on cardiovascular risk factors, however, are less well understood.

Objectives: We present the first longitudinal study on hyperlipidemia.

Methods: A within-person aanalysis addressed the question of whether a person tends to have higher cholesterol when her vitamin $D$ is lower than her average vitamin D. To assess this, for each visit, we calculated the difference between the vitamin $\mathrm{D}$ level at that visit and the person's average of vitamin D. Differences in the range of vitamin $D<50 \mathrm{ng} / \mathrm{mL}$ were distinguished from differences in the range above $50 \mathrm{ng} / \mathrm{mL}$. Then we modelled the relationship between these differences in vitamin $D$ and the difference between the person's cholesterol at each visit and the person's average cholesterol.

Results:

Table 1. Difference in Cholesterol at each visit per $10 \mathrm{ng} / \mathrm{mL}$ difference in between the patient's vitamin $\mathrm{D}$ at that visit and the patient's average vitamin $\mathrm{D}$

\begin{tabular}{lcccc}
\hline Range of Vitamin D & \multicolumn{4}{c}{$\begin{array}{c}\text { Estimated difference in cholesterol (relative to a patient's } \\
\text { average cholesterol) as a function of differences in a patient's } \\
\text { Vitamin D levels (relative to her average Vitamin D levels) }\end{array}$} \\
\cline { 2 - 5 } & Unadjusted & P-value & Adjusted $^{1}$ & P-value \\
\hline $0-50 \mathrm{ng} / \mathrm{mL}$ & $-3.4(-3.9,-2.9)$ & $<0.0001$ & $-3.1(-3.6,-2.6)$ & $<0.0001$ \\
$50+\mathrm{ng} / \mathrm{mL}$ & $-1.1(-1.7,-0.5)$ & 0.0003 & $-1.0(-1.7,-0.4)$ & 0.0016 \\
\hline
\end{tabular}

${ }^{1}$ Adjusted for age, age-squared, sex, race, proportion of time on Plaquenil, mean prednisone dose, mean BM and systolic blood pressure.

Table 2. Difference in Cholesterol per $10 \mathrm{ng} / \mathrm{mL}$ Difference in Vitamin D

Range of mean Vitamin D Estimated difference in cholesterol per $10 \mathrm{ng} / \mathrm{mL}$ difference in Vitamin D $(95 \% \mathrm{Cl})$

\begin{tabular}{lcccc} 
& Unadjusted & P-value & Adjusted $^{1}$ & P-value \\
\hline $0-50 \mathrm{ng} / \mathrm{mL}$ & $-3.7(-4.2,-3.2)$ & $<0.0001$ & $-3.0(-3.5,-2.4)$ & $<0.0001$ \\
$50+\mathrm{ng} / \mathrm{mL}$ & $-0.9(-1.5,-0.2)$ & 0.014 & $-1.1(-1.8,-0.3)$ & 0.0037 \\
\hline
\end{tabular}

${ }^{1}$ Adjusted for age, age-squared, sex, race, proportion of time on Plaquenil, mean prednisone dose, mean BMl and SBP.

This means that at a particular clinic visit, if a person's vitamin D is higher than the person's mean vitamin $\mathrm{D}$ by $10 \mathrm{ng} / \mathrm{mL}$ and the person has vitamin $\mathrm{D}$ below $40 \mathrm{ng} / \mathrm{mL}$, then the expected cholesterol will decrease by $3.4 \mathrm{mg} / \mathrm{dL}$. There is no significant effect of higher vitamin D among those whose mean vitamin D exceeds 50.

Conclusions: Vitamin D supplementation (in those whose level is below 40 $\mathrm{ng} / \mathrm{mL}$ ) has a significant benefit on total cholesterol that is independent of age, sex, ethnicity, Plaquenil, prednisone and body mass index. Vitamin D supplementation - as it also helps systolic blood pressure - is both important for SLE activity and for reduction of cardiovascular disease.

Disclosure of Interest: None declared

DOI: 10.1136/annrheumdis-2017-eular.1647

\section{AB0463 THERAPEUTIC PLASMA EXCHANGE (TPE) FOR REFRACTORY SLE: A COMPARISON OF OUTCOMES BETWEEN DIFFERENT SUB-PHENOTYPES?}

A. Soyuoz ${ }^{1}$, O. Karadag ${ }^{2}$, L. Kilic ${ }^{2}$, T. Karaagac Akyol ${ }^{3}$, S. Apras Bilgen ${ }^{2}$, O.I. Ozcebe ${ }^{4} .{ }^{1}$ Department of Internal Medicine; ${ }^{2}$ Department of Internal Medicine, Division of Rheumatology, Hacettepe University Faculty of Medicine; ${ }^{3}$ Blood and Apheresis Unit, Hacettepe University Hospitals; ${ }^{4}$ Department of Internal Medicine, Division of Haematology, Hacettepe University Faculty of Medicine, Ankara, Turkey

Background: Therapeutic plasma exchange (TPE) offers an alternative therapeutic modality for patients with systemic lupus erythematosus (SLE) and primary antiphospholipid syndrome (APS). However, there is conflicting evidence regarding its efficacy in different sub-phenotypes.

Objectives: This study aims to investigate the main clinical characteristics and outcomes of patients with different phenotypes of SLE and APS treated with TPE at a tertiary care centre.

Methods: Database of Blood and Apheresis Unit between 2001-2013 was screened for patients with SLE and primary APS. SLE disease activity index (SELENA-SLEDAI), the indications for treatment, complications and outcomes were obtained from review of medical records and phone calls. A total of 24 patients (SLE: 20, APS: 4) were recruited for the study.

Results: Mean ages of SLE (M/F: 1/19) and primary APS (PAPS) patients (M/F: $2 / 2$ ) were $32.4 \pm 12.89$ and $52.0 \pm 10.7$, respectively. The main indications for TPE were haematologic, neurologic, pulmonary involvement and APS-related. TPE was preferred in 8 patients because of leukopenia, and co-infection. SLEDAI was significantly decreased after TPE $(16.7 \pm 8.3$ vs. $8.8 \pm 3.1, p=0.001)$. Both primary APS and SLE related CAPS patients had completely responded to TPE. Success rate of TPE in patients with thrombocytopenia were lower than patients with haemolytic anaemia. Median (IQR 25\%>75\%) TPE sessions were 6.5 (5-10.5).

Table 1. Clinical, disease activity, treatment findings and TPE outcomes of SLE patients

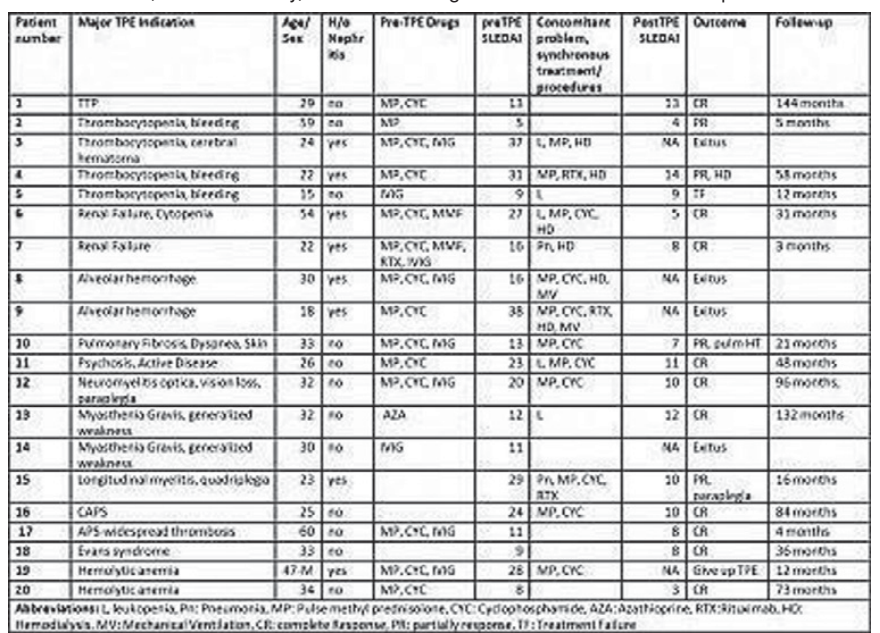

Conclusions: This study suggests catastrophic antiphospholipid syndrome (CAPS) and other APS related problems respond well to the TPE treatment. TPE should be kept in mind for the treatment of patients with other features of SLE, especially those resistant to other agents and in the presence of leukopenia and psychosis

Disclosure of Interest: None declared

DOI: 10.1136/annrheumdis-2017-eular.4426

\section{AB0464 AZATHIOPRIONE METABOLITES IN CONNECTIVE TISSUE DISEASE}

P. Pentony, T.Y.-E. Tsai. Rheumatology, the Canberra Hospital, Canberra, Australia

Background: Azathioprine (AZA) is a common treatment for connective tissue diseases (CTD). AZA is a pro-drug which is metabolised to active moieties of 